\title{
Miranda
}

Revue pluridisciplinaire du monde anglophone /

Multidisciplinary peer-reviewed journal on the English-

speaking world

5 | 2011

South and Race / Staging Mobility in the United States

\section{The Road West, Revised Editions}

\section{Audrey Goodman}

\section{OpenEdition}

\section{Journals}

Electronic version

URL: http://journals.openedition.org/miranda/2383

DOI: $10.4000 /$ miranda.2383

ISSN: $2108-6559$

\section{Publisher}

Université Toulouse - Jean Jaurès

\section{Electronic reference}

Audrey Goodman, "The Road West, Revised Editions", Miranda [Online], 5 | 2011, Online since 29

November 2011, connection on 16 February 2021. URL: http://journals.openedition.org/miranda/2383 ; DOI: https://doi.org/10.4000/miranda.2383

\section{This text was automatically generated on 16 February 2021.}

\section{c) (i) $९$}

Miranda is licensed under a Creative Commons Attribution-NonCommercial-NoDerivatives 4.0 International License. 


\title{
The Road West, Revised Editions
}

\author{
Audrey Goodman
}

1 In "Song of the Open Road" (1867), Walt Whitman, the great poet of American mobility, stepped out "afoot and light-hearted," feeling "healthy, free, the world before me." Proclaiming his own good fortune, he sought contact with the earth, the air, and the light-those elements he shared with his fellow Americans and which he claimed to possess through keeping his feet moving and his breathing deep. In the process, he projected unlimited freedom:

From this hour I ordain myself loose'd of limits and imaginary lines

Going where I list, my own master total and absolute

Listening to others, considering well what they say

Pausing, searching, receiving, contemplating

Gently, but with undeniable will, divesting myself of the holds that

would hold me.

I inhale great draughts of space

The east and the west are mine, and the north and the south are mine.

I am larger, better than I thought

I did not know I held so much goodness. (lines 53-61)

2 Here Whitman's conception of a road spans all directions. It entices the reader beyond any mapped route, into "pathless and wild seas" (line 125) and out into the universe, which can be known, the poet proposes, "as a road, as many roads, as roads for traveling souls" (line 180). His mobility was imaginary and local: Whitman walked down Broadway, through lower Manhattan and Brooklyn; rode the omnibus; traveled by ferry and train. Perhaps because of his intimate knowledge of the city, he could travel freely through territories that were not yet unified into a nation-and in fact would soon be divided by war and unevenly reconstructed into regions. His mobility was also formal, constitutive of his poetry in terms of flexible lines and wide-ranging catalogues. ${ }^{1}$ For Whitman, the figure of the road integrated material and imaginary ways of being, provided a means to organize space and movement, connected the disparate parts of his vision, and enabled him to imagine spanning a globe he could never fully traverse.

3 The possibilities the westward road presented for individual freedom and reconfigured social formations shaped the mythology of European-American and Anglo-American culture. The road suggests a geographical imagination that leads as far west as the 
Pacific and is democratically available, one in which places and cultures encountered along a particular route are equally accessible and comparable. If we consider the relation between the road and representations of place in American literature, we might see the road as strategy for staging and sustaining mobility and for resisting provincialism, those limitations in cultural perspective associated with staying still. Even in the twenty-first century the road remains a figure for modernization's spread, however antiquated it may be as a technology for transport and exchange. It also cannot be separated from the imperial history of nation-building that extended European domination across the territory that is now the United States. The road, in its representations and revisions, thus provides an opportunity to think critically about how places work on several levels: how they take shape in written and visual languages; how they contribute to the project of modernity; and how they provide a means to compare collective formations across space and time.

My models for rethinking the idea of the road come from Gayatri Spivak's defense of the intellectual process of wandering and her efforts to critique comparative literary study, as well as from Walter Mignolo's assessment of the field of Latin American studies. In a recent interview with Cathy Carruth, Spivak explained that wandering allows for the possibility of accidental discovery and resists the programmatic production of meaning. Her comments in this interview suggest a new approach to thinking about the ways that physical and intellectual mobility might be connected. Her essay "Rethinking Comparativism" (2009) and Mignolo's The Idea of Latin America (2005), meanwhile, urge re-consideration of the ways that constructions of identity through encounters with new places might distort or exclude indigenous languages and histories. Speaking of her early work as a comparativist, Spivak explains her earlier method of working with units of meaning which could be isolated and measured against one another: "What was especially useful for us in those early days was the study of topoi, sets of imageme-narrateme-philosophemes that seemed to travel without either historical or psychic ballast across the history of literatures and cultures that make us code geography, write our world" (Spivak 2009, 611). While such topoi allowed her to "think affinity in place of mere comparison," she now recognizes that "those great networks of affiliations work by way of exclusions" and warns that "to discover varieties of sameness is to give in too easily to the false promises of a level playing field" (611).

5 The physical process of wandering on and off the road has led to a great deal of our knowledge about the terrain and cultures of the United States, as well as to a rich literary record about how we imagine places and homelands. But in our current postcolonial moment, this history also poses troubling questions. Has the writing produced out of such wandering caused us to replace real differences with a fantasy of equivalence? To exclude or ignore elements of our history because they were less accessible or too difficult to translate? Or to pay too little attention to the idioms and languages that shape not only what we know but the way that we know? Mignolo seeks "to unravel the geo-politics of knowledge from the perspective of colonization, the untold and historically unrecognized counterpart of modernity" (xi). According to Spivak, one essential step in the decolonizing process of rethinking comparativism is to return to the study of language and the active process of translation-to the deep learning of a first language, whichever it may be, and to what she calls "the very moves of languaging."2 
6 While the process of translating the experience of place into language and literary form often emerged out of encounters on the road, even in the early twentieth century the road as a literary structure-a trope or chronotope-could not fully contain the meaning of these encounters. My research into the formation of Anglo-American culture in the American Southwest has focused on the ways that writers have tried to understand and translate experiences of western places into different literary and visual forms, from tour books and photographs to popular western novels, poetry, memoirs, and modernist fiction. I concluded in Translating Southwestern Landscapes that at least through the 1920s Anglo-Americans both recorded their first-hand observations of southwestern places and projected their desires onto these places. While recognizing that "[s]uch dreams of translation and such fascination with the dead and the inaccessible can unwittingly do violence to the living" (164), I also posed the question of whether outsiders could ever really imagine a native point of view. My recent reading of the literature of mobility produced in the western U.S. has led me to see that this opposition between outsider and native (one commonly discussed in scholarship on literary regionalism) oversimplifies differences in perspective that are shaped by culture, class, gender, and language as well as by location. Contemporary western writing and New Western history have proceeded to break down such binary oppositions by wandering off the beaten track or returning to sites left for ruin. In the process, they excavate previously untold histories of native landscapes, unsettle the dominant accounts of Anglo-European conquest, and restore rituals and narratives of everyday life told in native tongues.

7 In this essay I look at selected examples of such texts which continue to refigure the notion of mobility in order to question how modes of moving through space might shape both the form of writing and the way a writer imagines gaining access to language. I am especially interested in the ways that different kinds of mixed-genre texts-contemporary memoirs which are also natural and cultural histories, illustrated books, and bilingual poetry by indigenous writers-might reveal this process of entering into multiple languages and histories. I focus here on essays by William Kittredge and Ellen Meloy, photo-books by modernist photographer Edward Weston, and poems by Native American linguist Ofelia Zepeda to show how routes of exploration have yielded to sites of deliberate passivity, practices of wandering, and paths of return. My investigation thus seeks to combine ongoing challenges to the American West's history of imperialism with a new effort to animate "the very moves of languaging."

\section{Discovery and dispossession}

8 The routes to the western territories of North America produced singular, unrepeatable accounts of discovery and led to the violent conquest of lands and people. By returning to these original accounts and revising them, writers like William Kittredge and Ellen Meloy have produced powerful post-western narratives of displacement and new forms of landscape history. ${ }^{3}$ One example can be found in Kittredge's memoir Owning it All. "Home," the book's opening essay, describes the legendary winter walk on snowshoes taken by John Colter, a companion of Lewis and Clark, through what is now Yellowstone National Park. "Imagine those shining snowy mountains burning against the sheltering endless bowl of clear sky, and Colter alone there in Jackson Hole," 
Kittredge writes. "We will not see such things again, not any of us, ever. It's gone. We know it is. Only one man ever got to be Colter [...] Except for some natives, who maybe never thought they were alone" (6). Much has been made of how explorers engaged in real and visual colonization of western territories and imposed European conventions of scenery on the lands they discovered. Too little attention, perhaps, has been given to the freshness of the language and the newness of perception that came out of such wandering. Even in retelling this expedition, Kittredge acknowledges the power of the early Anglo explorer's mother tongue, the pain of his own loss of any original relation to the Western landscape, and the recognition that his own family history is complicit in Anglo-European imperialism.

Unlike Whitman, who imagined possession of the air, Kittredge begins with a refusal to claim possession of the land, for "the notion that my people live in a separate kingdom where they own it all, secure from the world, is still powerful and troublesome" (3). That notion itself was a myth, invented out of the failures of his ancestors to secure the homeland of their dreams. Kittredge's great-grandfather had traveled down the Mississippi to Panama, tried his luck in the gold camps in California, gave up and turned to ranching, and died in 1897, "white-trash poor in the sagebrush backlands near Silver Lake, Oregon" (8). Kittredge's response to this history of failed colonization is to compare his memory of the past with other versions of his region's past, wandering through various stories and allowing the disparities to resonate through time and space. Kittredge recounts strange and still unsettling encounters with local people, including a sometimes-violent ranch hand named Jack Ray and a Paiute girl who died too young, and with native species of animals. He remembers a disturbing confrontation with "a great strutting bird" which rose from a row of dry corn while he was working in the fields. Because he hated the job of laying damp burlap sacks on cucumber and tomato plants to protect them from frost, he daydreamed while he did it, making the sudden appearance of "black tail feathers flaring and a monstrous yelloworange air-sack pulsating from its white breast, its throat croaking with popping sounds like rust in a joint" all the more startling. As he recounts it, the bird seemed to come from another, less coherent and darker world and challenged the boy to stand up to its territorial claim:

The bird looked to be stalking me with grave slow intensity, coming after me from a place I could not understand as real, and yet quite recognizable, the sort of terrifying creature that would sometimes spawn in the incoherent world of my night-dreams. In my story, now, I say it looked like death, come to say hello. Then, it was simply an apparition. (9)

Kittredge proceeds to describe the courage he needed as an eight-year-old to hold his ground and confront the bird; in this encounter the bird staked its claim and conquered him. Despite the fact that he soon recognized the bird must be what his father called a courting sage-grouse, the act of naming dispelled neither his memory of fear nor his uneasy sense that this native bird was simultaneously "phantom and real" (10). The bird continued to occupy both his imagination and his family's territory. ${ }^{4}$ Toward the end of his essay, Kittredge asks, "Is it possible to claim that proceeding through some incidents in this free-associative manner is in fact a technique, a way of discovery?" (15). He ventures that the answer is, probably, yes, because only by giving voice to all memories, including those the colonizers might have chosen to repress, can the American West's multiple languages of longing and loss be found. 
11 Ellen Meloy's essays on the desert West collected in The Anthropology of Turquoise (2002) provide another example of the revisionary memoir. The very notion that a color, turquoise, is so connected with human society that it requires its own historical investigation already displaces the individual observer from the center of the inquiry. Meloy takes color as "her first principle of Place" (14) because "With every color lies a story, and stories are the binding agent of culture" (13). The many stories that turquoise specifically tells both connect disparate cultures and mark their differences: the Persians believe it makes eyes strong and protects against pain; the Zuni view turquoise as the embodiment of water; the Aztecs see it as nourishing the heart. For Meloy herself, turquoise comes to represent "all that a person can try to put into each of her days: attention to the radiance, a rise to the full chase of beauty" (322). Essential to her subject and method is the refusal of the color to be owned by the observer or fully contained by language, for "colors are not possessions; they are intimate revelations of an energy field" that convey sensation and make provisional connections between people and places.

Many of Meloy's essays play stasis against mobility, noting the traditional movement of native people (like the Navajo and the Mohave who wandered far beyond their traditional homelands) while cultivating her own practices of stillness and observation. Often she begins an exploration by looking carefully from a stationary place, whether a ridge made of sandstone or an unmarked place in the desert, and then pursues "an instinct of motion, a kind of knowing that is essentially indirect and sideways" (6). For example, in her opening essay she tests the feeling of stone and the meaning of colors, especially of blue (signifying concentric motion, according to Vassily Kandinsky), from the aquamarine of lichen to the indigo of the river to the turquoise of rock and sky. By focusing on varieties of turquoise here and throughout the book, she transforms the material world into waves, space into light, matter into energy, touch into language.

The essay "Azul Maya" describes her search for turquoise in the Yucatán Peninsula, which requires her to travel along a road cut violently through the jungle. She drives past "a fortress of slash-trees cut and piled as if there could never be a peaceful transition between closed and open space, between green wall and pale tarmac" (129)until she arrives at her destination, a coastal nature preserve where she can gaze at water and its layers of blue. It takes this brutal encounter with the destruction wrought by the development of the Yucatán for luxury tourism to bring her to the threshold of another world: she then gazes at the sea, feeling "as if I have crawled through an aperture in one of my horizon bands and emerged on the other side into turquoise writ large. The world layers itself in chromatic resonance from the horizon to my toes: deep indigo, aquamarine, turquoise, then water as clear as glass" (130). This discovery of the water's colors and the complex world of the coral reef that created it, of the distinctive pigment of Mayan azul and many untranslatable words for blue in the Mayan language, leads Meloy to feel lost and mute. Yet, by immersing herself in this other world and other culture, she deliberately resists the impulse to map and to name the place, and in the process she discovers, unexpectedly, that a decolonizing "happiness exists" (155).

Meloy's investigations of the visible and hidden lives in the land around her home on the Colorado Plateau also recognize that a wanderer might never gain satisfactory access to native histories, languages, and knowledge. Speaking of the traditional Mohave practice of walking through the desert, Meloy states: 
I bear no delusions that I could survive a Mohave walk. I know how to move my limbs in a desert, but I do not know anything-where to find water, how to pace a journey, what kind of snare would trick a rabbit, how to cook a yucca, how to make use of hallucinations, where to cross the serrated mountain ranges that rise up from the low-lying basins like the backs of a fleet of stegosauruses. If, here on a patch of desert south of Needles, California, I had native guides, perhaps I might go along as a topophiliac and a heavy dreamer, endearing myself to people for whom geography and dreams were nearly an obsession. The most difficult premise of this fantasy: how to envision the terrain of the pre-Columbian river people, how to make any progress once we trekkers took our very first step. The challenges to a twenty-first-century Mohave walk are formidable. (86)

Local knowledge means familiarity with not only how the land looks in the present but also with how people in the past learned to use, name, map, traverse, and symbolize the terrain. In this essay, "AhaMahav Walkabout," Meloy pursues each aspect of such knowledge in a circuitous fashion, working at times like Kittredge through freeassociation; at other points she moves between evidence gathered first hand through observation of the valley, through conversation, or from a variety of natural and cultural histories (including Pliny the Elder's Natural History from the first century AD and Alfred Kroeber's 1925 Handbook of the Indians of California). Having fallen "off the landmarks into the map's blank spaces" (80), she takes on the task of integrating her sources and mapping her own indirect path.

16 On one occasion of wandering the Mohave, Meloy discovers a magnificent maze made of rocks tamped by hand. The maze covers ten acres and originally included an intaglio of a man and a snake 150 feet long and 60 feet wide. Investigating the site, Meloy struggles to determine its age. She discovers that it "likely predates European contact;" that the Fred Harvey Company promoted it on postcards as "the Mystic Maze of the Mojave Indians"; and that the Mohave claimed as work of the "old ones" done to capture evil spirits floating down the Colorado River (while the newly released soul would continue to the land of the dead, where it would die again and be cremated by other ghosts). Over time large parts of the maze have been destroyed by bridge, railroad, and highway construction through its heart; by vandalism; and by a motorcycle race course. However, Meloy proposes that "[i]f you peel off the highways, reservoirs, compression plant, railroad track, and a number of centuries, the paths seem to honor a different miracle" (93): that of a "route [that] might lead to nothing else but a necessary faith in time" (94).

Like many of Meloy's essays, the "ahaMakav Walkabout" narrates and compares ways of moving through space and approaching an alternate world; it arrives at a destination by standing still and letting go of control over time, consciousness, and language. Thus Meloy follows the model not of the Anglo explorers who preceeded her but of the Mohave and other Colorado River people who organized their lives by rituals and responded to their physical environment and their dreams by shaping experience into "song-stories." Meloy finally writes her own desert song-story by combining the traditional form with her own observations of the landscape. She starts with the model "fear slough/fat earth/duck water/no water" (100), a story of a journey whose meaning could only emerge through patterns familiar to the Mohave people. "Mohave men dreamed in familiar mythic patterns, and the stories, in turn, provided a framework for interpreting the content of dreams" (Furst 32). Meloy's adaptation instead makes concrete the contemporary reality of her inhabited and far-from-pristine desert west: "electrified campground/pipeline hydrocarbons/the boulder where the raven poops 
and drops her french fry/starts visible, ghost gorge not/designer water/motorhead water/no water/and oh dear God my river" (101). In an effort to connect the indigenous practice of expressing dreams in poetic form with her own cultivation of the practice and poetics of sensation, Meloy sets "geography to voice" (101) and finds a new language for interpreting her relocated life.

\section{Edward Weston's road trips}

By the late nineteenth century, the frontier had closed, and people who had already settled in the mid-West went farther, to the West coast. By the early twentieth century, wagon routes and train travel yielded to automobile trips, and in the process, the road became a new kind of social and private space, as landscape historian J. B. Jackson has eloquently explained. Because Americans believed in mobility, they built landscapes that facilitated speed, efficiency, and privacy-with roads at the center. What "started out as a wavering line between fields and houses and hills [...] then took over more and more land, influenced and changed a wider and wider environment until the map of the United States seemed nothing but a web of roads and railroads and highways," Jackson explained-a list we might extend to include grids, satellite lines, networks, and webs (Necessity for Ruins 122). Such webs might be considered physical preparation for the network of global capitalism, which Stephen Tatum describes in "Spectrality and the Postregional Interface" as a hypermobile process that imagines the regional or the local as "a postindustrial nodal point where the global flows of capital, commodities, peoples, and images intersect" (11). According to Spivak, such capital "moves always with the same kind of value, grinding everything into commeasurability" (Interview 1021). No wonder photographers who sought to document the American landscape in the mid-twentieth century, such as Walker Evans, Edward Weston, and Robert Frank, struggled to find their own languages outside of the newly standardized highway system, through wandering off official routes.

Both of Weston's major book publications, California and the West (1940) and Leaves of Grass (1942), came out of road trips. The first resulted from the two years he spent traveling through the West with Charis Wilson on a Guggenheim fellowship in 1937-39; the second was commissioned by the directors of the Limited Editions Club to illustrate a re-issue of Walt Whitman's poem. In his Guggenheim application for the project that would become California and the West, Weston wrote that he believed "whatever exists in the rest of the world-from glacier to active volcano-is somewhere represented here" (Weston125). The book encompasses not only natural sites but also the region's wildly diverse landscapes of cultivation and desolation. Weston framed land settled through traditional methods of building and farming, as well as those places left behind during modernization. He was especially compelled by the movement of clouds and by the scale and changeability of Death Valley, which challenged his ability to find order in nature. Throughout this trip, he welcomed the "loss of control" that Spivak advocates as an essential condition for aesthetic discovery.

What happened, then, when Weston followed the road back east and searched for the visible outcome of American ambition across an even wider range of highways and back roads? On a practical level, there was the problem of clothing (as Wilson put it in her unpublished notes, they were "such utter Californians, and coastal Californians are the utterest"); weather ("For the first time I realized what impossible weather the rest of 
the country was exposed to"); and speed (there was no way to avoid highways and or to manage a "running account" along the way, as she had done with California and the West). ${ }^{5}$ On a conceptual level, though, there was the problem of approaching the differences presented by the landscape, because each place displayed such powerful evidence of uneven development. In Arizona, Weston and Wilson visited a Yaqui village and learned as they left Tucson that the Nazis had just declared war on Russia; in New Mexico they felt again the absence of development, compared with California; in Texas, they listened to storytellers, including Frank Dobie, whose storytelling would be eclipsed by radio, and soon by television; in New Orleans, they probed the city's Creole culture through the fascinating life of the cemetery; in metropolitan Chicago, they found the view of the industrial landscape from the Pulaski Skyway to be "the most terrific thing we've seen." There was perhaps "more openness to variety, contingency, the unexpected" in this project, as Alan Trachtenberg has observed ("The Final Years" 290). Still, neither the people nor the landscape could be fit into Whitman's summation of America.

This revision of Leaves of Grass proves that by the mid-twentieth century the view from the road and the idea of America could no longer be dissociated from national and global flows. From this historical moment on, the electronic and transportation networks, the virtual technologies, and the flow of images from the entertainment industry sector" "could be described as composing a postregional grid" (Tatum 13), one that creates spaces of movement rather than sequences of local places seen from the road and framed by a camera's lens. In his effort to re-make Whitman's vision through a sequence of photographs of the contemporary landscape, Weston both revealed the difficulty of retracing the imaginative route of his nineteenth-century model and articulated his resistance to the dominant contemporary conception of the U. S. as a uniformly powerful and privileged nation. This photo-book registers a critical disjunction between earlier methods of integrating disparate cutures and landscapes (such as Whitman's catalogs and his revisionary process) without arriving at a successful new formal combination for conveying the landscape's diversity and contested histories. Whitman alone may have been able to transform individual feelings of isolation, difference, and mortality into a poetics of unity, although later works such as Democratic Vistas and "Passage to India" written after the Civil War reveal a marked "ambivalence evoked by the prospect of unmapped [global] spaces" (Hsu 142). For Weston, the only part of the American landscape that that remained whole-and perhaps impossible to frame-was the view from his house at Carmel, on the nation's westernmost coast, of the ever-changing Pacific.

\section{Ofelia Zepeda's vagrant clouds}

My final example of a comparative poetics of wandering comes from Ofelia Zepeda, a poet who lives in Tucson and on the Tohono O'odham reservation which extends across the U.S.-Mexico border. ${ }^{6}$ Zepeda writes from a clear sense of cultural location, which she often expresses in her mother tongue. ${ }^{7}$ As she notes in her second collection of poems, Ocean Power, her native language is related to Pima, Yaqui, Hopi, and others in Mexico and further south; it "is still spoken by many members of the tribe" and "is rich in many forms of oral texts" (Zepeda 87). However, “[w]ritten O'odham is a relatively new creation" (87). To write down a song or verbal utterance is already an act of 
translation that requires cultural and linguistic mobility. Many of Zepeda's poem titles refer to songs, alluding to their traditional origins. Some mix stanzas or refrains or words in O'odham with those in English, or imitate the structure of repetition common to O'odham songs and prayers. In both Ocean Power (1995) and Where Clouds Are Formed (2008), Zepeda excavates the sensory language of individual and tribal memory, locating home in the scent of burning mesquite, cedar, piñon, or juniper wood, or in the texture of smooth mud walls. Each of these strategies maintains a connection to the spoken language Zepeda learned first (as well as to the cultural formation such language learning implies) while experimenting with alternative written versions through bilingual forms. If "translation is the most intimate act of reading", as Spivak claims ("Rethinking" 613), then Zepeda's poetry provides us with maps for this intimate act-and the opportunity to rethink how memories of learning and using two different languages could point us towards ways of reading places and texts outside of regional, national, and other geo-political frameworks.

Consider Zepeda's road poem, "Blacktop", which signifies on and revises the trope of Whitman's "Open Road" to engage in a deep comparison between the lure of possibility and the meaning of a tribal homeland. The blacktop carries the speaker beyond the built environment and into the desert's shimmering, inarticulate territory, places where the voices of weavers "drift into/The tangle of desert where all language goes" (Where Clouds Are Formed 65). By yielding to the road as Meloy yielded to desert and sea, Zepeda opens herself to disorientation and the possible discovery of language's future destination. "Leaving the debris of my life under a mesquite tree,/I rush towards an imaginary new life", she writes. Zepeda then continues to specify the intimacy of her relation to the road: "The blacktop carries me in all directions./It knows my name./I never told it my name./It calls me" (65). Suddenly, the road becomes animate, a companion, an embodiment of equal, if contradictory desires. And when it speaks to her, it offers the promise that she will carry the places she values, such as the mountain sacred to her people, and her mother tongue with her:

It wants to carry me in all directions.

It whispers, "You will always see Waw Giwalik

In your rearview mirror." (66)

In O'odham, "Waw Giwalik" means indented rock or peak (Saxton 437); it refers to Baboquivari Peak, believed by the O'odham to be the place of first emergence after the world flood. Many O'odham visit the mountain as a shrine and leave offerings for good luck. Here Zepeda confirms the grounding power of this place of origin while pursuing the open routes of discovery made possible by the blacktop, combining traditional knowledge and modern mobility. Such juxtapositions of first and second languages, and of ritual and contingency, lie at the heart of Zepeda's poetics.

In other poems, instead of traveling or wandering herself, Zepeda observes the vagrant movement of the natural world. In "Cloud Song", she translates natural motion into color and selects a single location from which she can observe the moving sky. She notices, "Greenly they emerge./In colors of blue they emerge./Whitely they emerge./ In colors of black they are coming./Reddening, they are right here" (Zepeda 1995, 15). The speaker of Zepeda's poem stays still, leaving all the mobility to the clouds above; in this way she re-asserts her identity as an O'odham person. It is tempting to read this poem in terms of affinities: to William Wordsworth's "I wandered lonely as a cloud", for instance; to Alfred Stieglitz's series of cloud photographs he called Equivalents or Songs 
of the Sky; or to Weston's extensive studies of clouds above Mexico and the Western U. $\mathrm{S}$. As Spivak suggests, however, such comparison of tropes of mobility runs the risk of a false "discovery" of sameness that too easily dismisses differences in power, culture, and language. Instead, new practices such as Zepeda's are needed. Rather than declare such continuities across cultures, such critical comparativism delves more deeply into the particular languages and forms of both native and decolonizing aesthetics. While it may be difficult for a writer or reader to become fluent in many languages, she can pursue a comparative aesthetics and thus develop the ability to register the affective differences between first and other languages.

Aware of her people's histories of forced migration, Zepeda responds with alternate ways of locating identity in and moving through the landscape, often returning to traditional, even outdated modes of travel (walking, wandering), in order to find deeper maps and render cultural comparison in new forms. ${ }^{8}$ She repeatedly asserts her identity as one of the "real desert people" who try to "pull down the clouds" and "ift their faces/upward with the first signs of moisture". Unlike newer transplants who pride themselves on merely surviving a June day in Tucson, Arizona or those who move from one air-conditioned environment to another, her people "know how to inhale properly" ("Proclamation", in Zepeda 2008, 44). The speakers with whom she identifies might have left their native lands, but they also struggle to articulate the rhythms and rituals of home. For example, she explains about her poem "Ocean Power" that she chose to write "about two O'odham men who came too close to the ocean as they were being deported back to Mexico from Arizona" (Zepeda 1995, 86). They knew about "That land of hot dry air/where the sky ends at the mountains", but their sudden view of the ocean produced "dry fear in their throats". "We do not belong here,/this place with the sky too endless" she explains through their collective voice. Not only is the "air too thick and heavy to breathe":

We are not ready to be here.

We are not prepared in the old way.

We have no medicine.

We have not sat and had our minds walk through the image of coming to this ocean.

We are not ready.

We have not put our minds to what it is we want to give to the ocean. (Zepeda 1995,

84)

27 Following the syntactical structure of a traditional song, the poem continues to contemplate the questions the men might have chosen to ask of the sea, the blessings they might have sought-if they had taken the proper road west.

A traditional O'odham journey to the ocean would probably have been a pilgrimage for salt, an expedition undertaken with great deliberation by each village and guided by a recognized leader. Along the way, the leader would have initiated recitations and songs and made sure that everyone stayed on the trail, spoke slowly, carried an offering of corn meal, and planted prayer sticks appropriately at each water hole. A speech called The Preparation would have put the traveler in the right frame of mind to receive visions at the ocean. Finally, upon arrival, the travelers would have thrown cornmeal in the waves, delivered an invocation, and completed their pilgrimage with purification rituals. Each stage of the journey would have required specific speeches or songs adapted for the group or occasion, and the pilgrimage as a whole would have aimed to transfer some elemental force to the traveler. ${ }^{9}$ In "Ocean Power" Zepeda seems to allude to this ritual and thus implicitly records its loss. But she also writes the story of 
this singular return into a new ritual, using poetic language that combines traditional forms of recitation with contemporary speech. Thus she presents even a forced repatriation as a journey worthy of respect and celebration. The bus driver in the poem, like a reader lacking knowledge of O'odham ritual, cannot fathom these negotiations-and his dismissal of the ocean's significance marks the new territory the translator or poet must traverse. In her revised editions of the road west, Zepeda crosses this territory and moves between languages to speak the power of tradition, memory, sensation, and imagination; in the process, she leads us back again towards the "pathless and wild seas."

\section{BIBLIOGRAPHY}

Furst, Jill Leslie. Mojave Pottery, Mojave People: The Dillingham Collection of Mojave Ceramics. Santa Fe: School of American Research Press, 2001.

Goodman, Audrey. Lost Homelands: Ruin and Reconstruction in the $20^{\text {th }}$-Century Southwest. Tucson: University of Arizona Press, 2010.

--- . Translating Southwestern Landscapes: The Making of an Anglo Literary Region 1880-1930. Tucson: University of Arizona Press, 2002.

Hsu, Hsuan L. Geography and the Production of Space in nineteenth century American Literature. New York: Cambridge University Press, 2010.

Jackson, J. B. Landscape in Sight: Looking at America. Ed. Helen Lefkowitz Horowitz. New Haven: Yale University Press, 1997.

King, Thomas. Truth and Bright Water. New York: Grove Press, 1999.

Kittredge, William. Owning It All. Saint Paul, MN: Greywolf Press, 1987.

Meloy, Ellen. The Anthropology of Turquoise. 2002. Repr. New York: Vintage Books, 2003.

Mignolo, Walter. The Idea of Latin America. Malden, MA and Oxford, UK: 2005.

Miller, Matt. Collage of Myself: Walt Whitman and the Making of Leaves of Grass. Lincoln and London: University of Nebraska Press, 2010.

Saxton, Dean and Lucille. Legends and Lore of the Papago and Pima Indians. Tucson: University of Arizona Press, 1973.

Silko, Leslie Marmon. The Turquoise Ledge. New York: Viking Press, 2010.

Spivak, Gayatri. "Rethinking Comparativism.” New Literary History 40 (2009). 609-626.

--- and Cathy Carruth. “Interview with Gayatri Chakravorty Spivak.” PMLA 125: 4 (October 2010). 1020-25.

Tatum, Stephen. "Spectrality and the Postregional Interface." Postwestern Cultures: Literature, Theory, Space. Ed. Susan Kollin. Lincoln and London: University of Nebraska Press, 2007. 3-29. 
Teuton, Sean Kikummah. Red Land, Red Power: Grounding Knowledge in the American Indian Novel. Durham and London: Duke UP, 2008.

Trachtenberg, Alan. “The Final Years.” Edward Weston: Forms of Passion. Ed. Gilles Mora. New York: Harry Abrams, 1995. 288-94.

Underhill, Ruth M. Papago Indian Religion. New York: AMS Press, 1969.

Weston, Edward. Leaves of Grass by Walt Whitman. New York: Paddington Press Ltd, 1976.

--- and Charis Wilson. California and the West. New York: Duell, Sloan and Pierce, 1940.

Wilson, Charis. Unpublished manuscript. Pasadena, CA. Huntington Library.

Whitman, Walt. Leaves of Grass and Other Writings. Ed. Michael Moon. New York: Norton, 2002.

Wordsworth, William. The Poems: Volume One. Ed. John O. Hayden. New Haven: Yale University Press, 1977.

Zepeda, Ofelia. Ocean Power. Tucson: University of Arizona Press, 1995.

---. Where Clouds Are Formed. Tucson: University of Arizona Press, 2008.

---, ed. When It Rains: Papago and Pima Poetry. Tucson: University of Arizona Press, 1982.

\section{NOTES}

1. For a fascinating discussion of Whitman's compositional method, see Miller, Collage of Myself.

2. In terms of methodology, such comparative work requires an aesthetic education, one that according to Spivak puts primacy on reading and language immersion; allows for the accidental; contemplates meaning in singular or unverifiable occurances; and lacks any guarantees about the future or the result.

3. Other examples of this contemporary post-western writing range in genre from personal essays (by writers like Kittredge, Rebecca Solnit, Scott Momaday, and Leslie Silko) to practices of New Western History (by Patricia Limerick and Jake Kosek), ethnopoetics and ethnobotany (by Dennis Tedlock, Gary Paul Nabhan, Cheryl Glotfelty and Tom Lynch), landscape photography (Peter Goin, Joan Myers), and poetry (by Luci Tapahanso, Joy Harjo, Simon Ortiz, Ofelia Zepeda). For a consideration of how some of these literary and visual forms re-imagine the native histories of the southwestern U.S., see my Lost Homelands: Ruin and Reconstruction in the 20th-Century Southwest (2010).

4. In a similar strategy of juxtaposition, Kittredge layers the histories of Paiute involvement in the Ghost Dance at Surprise Valley, on the Oregon border, with accounts of traditional Paiute healing practices and belated expressions of grief at the Paiute girl's death, leaving each version of disappointment and failure raw and exposed.

5. See Charis Wilson's unpublished notes at the Huntington Library, Pasadena, CA.

6. Currently a professor of linguistics at the University of Arizona, Zepeda was born and raised in Stanfield, Arizona, a rural cotton-farming community. She wrote the first grammar of the Tohono O'odham language, A Papago Grammar, published three collections of poetry, and edits a series of Native American books called Sun Tracks. She 
was awarded a MacArthur Fellowship for her work in American Indian language education, maintenance, and recovery.

7. Like many indigenous people, instead of seeking cultural knowledge through the mobility, the O'odham "understand themselves and their attachment to land through tribal stories about the history of that land, contained in the oral tradition" (Teuton 44). The primary relation that Indigenous people have with the land leads to "everything else-identity, history, culture" (45).

8. Zepeda's most recent poems articulate the pain and frustration many O'odham encounter when trying to recover their mother tongue. For example, a speaker might be confused by a joke told in O'odham or unable to gain access to the "million pieces of information" in her grandmother's mind. See "Walking with Language" and "Pain of Speaking" (Zepeda 2008, 63-64).

9. Ruth Underhill's Papago Indian Religion provides an account of this ritual pilgrimage and includes examples of songs and speeches. One leader's speech describes the acquisition and transmission of the power he obtained during his pilgrimage: "The powers I had won beneath my bed I place./I lay upon them and lay down to sleep./ Then, in a little time mysteriously there came to me/Beautiful drunken songs;/ Beautiful songs for the circling dance;/Beautiful songs for the maiden's dance, / Wherewith the maiden I might cozen /My songs the stay-at-home youths did learn and sing, /Scarce permitting me to be heard./ With my songs the evening spread echoing, / And the early dawn emerged with a good sound, /The firm mountains stood echoing therewith, /And the trees stood deep rooted." (229)

\section{ABSTRACTS}

This essay explores the relation between the trope of the road and comparative representations of place in North American literature through the lens of recent critiques of comparative literature and area studies. Beginning with the assertion of Walt Whitman's "Song of the Open Road" as a key figuration of the mobile imagination essential to the modernizing processes of migration and imperialism in the U.S., the essay analyzes significant revisions of Whitman's vision by essayists William Kittredge and Ellen Meloy, photographer Edward Weston, and poet Ofelia Zepeda. It argues that these mixed-genre and multilingual revisions of the idea of the road west provide new models for writing about local places in a time of globalization.

Cet essai étudie la représentation du trope de la route dans la littérature Nord-Américaine à travers le prisme de recherches récentes en littérature comparée et area studies. S'ouvrant sur la déclaration de Walt Whitman dans "Song of the Open Road" et sa représentation de l'imagination comme mobile, une représentation emblématique des processus modernes de migration et d'impérialisme aux USA, cet article analyse les relectures significatives de la vision de Whitman par les essayistes William Kittredge et Ellen Meloy, le photographe Edward Weston, et la poètesse Ofelia Zepeda. Nous démontrerons que ces relectures hybrides et multilingues de l'idée de la route vers l'ouest proposent de nouveaux modèles pour écrire le local à l'heure de la mondialisation. 
INDEX

Keywords: American West, Comparativism, genre, landscape, mobility, road, Tohono O'odham Mots-clés: études comparatives, genre, Ouest américain, paysage, mobilité, route, Tohono O'odham

\section{AUTHORS}

\section{AUDREY GOODMAN}

Associate Professor of English

Georgia State University

agoodman@gsu.edu 